\title{
All lost and in one day
}

\author{
David Jolley
}

November 30th 1995 saw old age psychlatiy lose the active services of four men who have played herolc roles in creating and moulding the speciality.

Tom Arie, Klaus Bergmann, Brice Pitt and Raymond Levy were honoured by a meeting of the Section of Old Age Psychiatry within the Royal College of Psychiatrists. They told an audience of over 100 consultants and senior registrars about their early meetings in the coffee shops of North London in the $1960 \mathrm{~s}$. These proved to be the beginnings of a powerful movement, strengthened by its lack of fashion, driven by a desire to understand more about mental disorder among older people and by a conviction that much. much more could and should be done for the health and welfare of older people who suffer from mental illness.

Klaus Bergmann described his own introduction to the work as a research worker with David Kay and Martin Roth seeing over 700 'normal' older people on the streets of Newcastle upon Tyne. That epidemiological work and his own analysis of neurotic disorders among older people, have remained firm foundations of further developments in the years between. He reflected that he had lost out in competition for the first ever old age psychiatry consultant post advertised in this country to his colleague of the day, Brice Pitt. Yet he went on to initiate fabulous services for the people of Brighton before returning to Newcastle to establish the very productive (new) Brighton Clinic. More recently he succeeded one of his heroes, Dr Felix Post, as Consultant to the Maudsley Hospital. Klaus congratulated us all for the improvements that have been achieved in the structuring and provision of services, but warned us not to lose sight of the really important matters and sources of joy arising from clinical involvement with patients and their families. It would be a sterile world indeed should we fail to heed that advice.

Tom Arie reminded us of our debts to previous Chairmen of the Section, including Felix Post, and the strength and 'know how' we gained from colleagues in gerlatric medicine, including Jimmy Williamson, Bernard Isaacs, John Brockelhurst and others. He also reviewed the extraordinary evolution of the service at Goodmayes Hospital in Essex
Tom Dunn, a redoubtable, unsung geriatric physician glowed with pleasure and the pride of it all those 25 years ago. Tom Arie's slides included pictures of international friends who have carried the gospel through Canada, Australia and other parts of the world and who are personally thankful to Tom for his encouragement and inspiration. The world community of older people will always carry the same debt. Finally there were 'ourselves': many members of the audience, younger and older and knowing that we remain the future.

Brice Pitt gave warning that he had not been feeling too well and that his voice was not up to scratch, but it did not show. This immense figure with his dramatic voice held us enthralled as he has so many times with his grasp and his memory and his flare to breathe life into shadows. His chosen theme was the achievements of the three others who joined with him in the departure of the day, setting the triumphs in context alongside the work of others who had not necessarily committed themselves wholeheartedly to work within the field, but had sometimes been involved in research that had been helpful.

Brice told us much about other people and what they had done, but we knew that Brice had pioneered academic old age psychiatry in the London Hospital and had popularised the work through his little book on the subject written, it is fabled, in one week which became a best-seller. He had moved on from the London for a short stay at St Bartholomew's and latterly to the Chair at St Mary's, attracting large numbers of people to work with him. His cultured bonhomie and generosity to colleagues in all fields have ensured that suspicious colleagues within the rest of psychiatry allowed the sparky adolescent old age psychiatry to mature into an independent composed and helpful member of the family.

Raymond Levy declared that his personal frame of mind and emotion at the present was such that he could not talk, but we loved him well for that

We said our thanks for these four great men. We remembered others who had passed into retirement and some onto death; Felix Post, Gordon Langley, Torquil MacLeod, Tony Whitehead, Garry Blessed, Loic Hemsi, David Neal, Isabel Moyes. We looked around and saw that others will follow soon, for the cohort of founder 
members of the late 60 s and early 70 s are now themselves entering the community of old people that they have served so well.

Certainly they must be encouraged to remain part of the family as they explore further the possibilities of life in the seventh, eighth and ninth decades. They know that there is now a large and growing group of people who will give their lives to similar work. But which of us will measure up to these four great men?

David Jolley, Consultant Old Age Psychiatrist, University Hospital of South Manchester and Wolverhampton Health Care

\section{New from Gaskell}

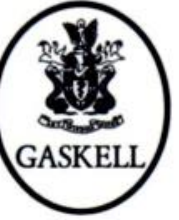

\section{MentalDisordersinChina}

\section{English Version Editors: John E. Cooper \& Norman Sartorius}

This is the first available account in English of the results of the 1982 Chinese Epidemiological Survey of Mental Disorder. It is the only nationwide Chinese study to involve modern methods of case assessment and is uniquely large and interesting; 12 centres in different parts of China studied a rural and an urban sample of 500 households each, giving a total sample of 51982 persons. The use of the Present State Examination in the survey allows the symptomatic basis of diagnoses, such as neurasthenia, to be examined. The results indicate that the prevalence of schizophrenia is similar to that found recently in other countries, but that the prevalence of other mental disorders may be lower. Readers may also be interested to purchase Mental Health Care in China, published in 1995, price $\mathrm{E} / 2.50$.

\section{Price $f \mid 5.00$ I 128pp. 1 I 996 I ISBN 0 90224I 93 I}

Available from good bookshops and from the Publications Department, Royal College of Psychiatrists, I 7 Belgrave Square, London SWIX 8PG (Tel. 0I 7 I-235 235I, extension 146) 